DOI: https://doi.org/10.32782/2410-0927-2020-13-5

УДК 811.161.2’373.4-053.6(477)+811.111’373.4-053.6(7)

Тетяна Бондар, Тетяна Рудая

\title{
КОНЦЕПТОСФЕРИ УКРАЇНСЬКОЇ ТА АМЕРИКАНСЬКОЇ МОЛОДІ
}

У статі розглянуто ключові поняття когнітивної лінгвістики («концепт» та «концептосфера») й основні методи їх дослідження, зокрема процедуру проведення вільного асоціативного експерименту. Асоціативні експерименти дають можливість отримати спонтанні та неупереджені реакції, що відображають спосіб мислення респондентів, їх сприйняття навколишньої дійсності, і виокремити концепти, котрі утворюють концептосферу окремого індивіда, певної групи людей чи народу.

Для опису концептосфер української та американської молоді проведено вільний асоціативний експеримент за участю 60 респондентів (30 українців та 30 американців) віком 18-25 років. Експеримент був анонімним, тому гендерні відмінності / подібності не розглядалися. У результаті проведеного експерименту отримано 591 асоціацію (респонденти-українці надали 291 реакцію, американці - 300). Слова-реакції є вербалізаторами концептів, актуальних для української та американської молоді. Найчастотніші концепти утворюють ядро концептосфер, вербалізаторами цих концептів є слова-реакції з частотністю 6 та вище. Приядерну зону концептосфер утворюють концепти, вербалізовані реакціями 3 частотністю 5-2. Одиничні реакції репрезентують концепти, які формують периферію концептосфер.

Ядро концептосфери україномовної молоді утворюють 10 концептів (СІМ'Я, КОХАННЯ, ЩАСТЯ, ДРУЗІ, ЗДОРОВ'Я, РОЗВИТОК, ДРУЖБА, ПОДОРОЖ, ДІТИ, УСПІХ), ядро концептосфери американської молоді - 12 концептів (LOVE, FAMILY, FREEDOM, FRIENDS, TRUST, HEALTH, LIFE, MONEY, HAPPINESS, FAITH, PEACE, LOYALTY). Експеримент засвідчив, що ключові концепти двох концептосфер не є унікальними, тобто вони практично не відрізняються в українців й американців. Проте спостерігаємо певні відмінності щодо важливості концептів.

Аналіз приядерної зони та периферії концептосфер української й американської молоді підтвердив, що набір концептів, які є актуальними для двох лінгвокультур, є дуже схожим, проте низка концептів, які утворюють приядерну зону концептосфери українців, потрапляє на периферію концептосфери американців, і навпаки: концепти, що належать до приядерної зони концептосфери американської молоді, за даними експерименту, утворюють периферію концептосфери українців. Таким чином, не зважаючи на одиничні, унікальні асоціації, отримані від представників двох лінгвокультур, експеримент показав, що складовими частинами концептосфер української та американської молоді є переважно концепти, які мають відповідники в обох лінгвокультурах.

Ключові слова: концепт, концептосфера, ядро, приядерна зона, периферія, асоціативний експеримент.

Вступ. Сучасна когнітивна лінгвістика - це мовознавчий напрям, завдання якого дослідження ментальних процесів, видів і форм їх презентації під час процесу пізнання, осмислення та пізнання свідомістю дійсності [2]. Одним 3 основних понять когнітивної лінгвістики є поняття концептосфери, яка складається 3 одиниць ментальної інформації концептів. Мова - продукт пізнавальної діяльності людини - надає найкращий доступ до вивчення структури та наповнення концептів.

Незважаючи на те, що питання концептосфери дослідники вивчають уже не одне десятиліття, у сучасному мовознавстві не існує єдиного визначення цього поняття. Питання вивчення концептосфер та їх класифікація залишаються надзвичайно актуальними, оскільки відображають уявлення людей про світ і відмінності в культурному досвіді як окремих осіб, так і цілих народів.

Значний внесок у вивчення концептів та концептосфер зробили українські дослідники, а саме: І. Голубовська, С. Жаботинська, В. Жайворонок, А. Загнітко, Т. Космеда, А. Приходько, Т. Радзієвська, О. Селіванова та ін. Серед зарубіжних дослідників чільне місце в цій галузі належить таким науковцям, як Н. Арутюнова, А. Бабушкін, Є. Бартмінський, М. Болдирєв, А. Вежбицька, С. Воркачов, В. Карасик, О. Кубрякова, Д. Лихачов, В. Маслова, С. Нікітіна, М. Піменова, 3. Попова, О. Рудакова, Г. Слишкін, Й. Стернін, Ю. Степанов, В. Телія, Р. Джакендофф, У. Чейф тощо.

Мета нашого дослідження - виокремити концепти, які формують концептосфери української та американської молоді.

Мета дослідження передбачає виконання таких завдань:

(C) Бондар T., Рудая T., 2020 
- провести вільний асоціативний експеримент 3 представниками української та американської молоді;

- виокремити концепти, які утворюють ядро, приядерну зону та периферію концептосфер двох лінгвокультур;

- здійснити порівняльний аналіз наповнення концептосфер української та американської молоді.

Методи та методики дослідження. Для опису концептосфер української та американської молоді ми провели вільний асоціативний експеримент за участю носіїв відповідних мов.

Асоціативні підходи $є$ пріоритетними у вивченні мовної свідомості, адже вони забезпечують спонтанність на неупередженість у реакціях респондентів. Асоціативний експеримент дає змогу з'ясувати, як проявляються індивідуальні, групові та ментальні характеристики особистості в асоціативному процесі. Асоціації відображають не лише мовну свідомість, а й метафоричне зображення дійсності, фрейми характерних національно-культурних ситуацій, складові частини національної самосвідомості, національні оцінки та вподобання [1].

Більшість асоціацій є типовими, не унікальними; тому асоціативні експерименти відображають мовну реальність, характерну для певної лінгвоспільноти.

Вільний асоціативний експеримент може бути проведений в усній чи письмовій формі, груповій чи індивідуальній. У цьому дослідженні ми віддали перевагу письмовій, індивідуальній формам проведення експерименту, що мають певні обмеження в часі. Така форма проведення асоціативного експерименту дає можливість виявити спонтанні асоціації, позбавлені впливу інших осіб. Найчастотніші асоціації (реакції респондентів) утворюють ядро концептосфери народів, менш уживані асоціації належать до периферії концептосфери.

У нашому експерименті взяло участь 60 осіб (30 українців та 30 американців) віком від 18 до 25 років. Уважають, що в цьому віці майже завершується формування мовних здібностей. Власне, тому ми обрали молодіжну аудиторію для проведення експерименту.

Здійснення нашого вільного асоціативного експерименту передбачало такі етапи:

- створення онлайн-анкет, які повинні бути зрозумілими та доступними для учасників експерименту, у яких буде передбачено достатньо місця для того, щоб записати 10 асоціацій;

- підбір українських та американських респондентів, які будуть підходитимуть під вибрану вікову категорію - 18-25 років;

- дистанційне проведення експерименту;

- опрацювання отриманих даних та здійснення кількісних обрахунків;

- визначення ядра концептосфери української та американської молоді;

- здійснення порівняльного аналізу наповнення концептосфер української та американської молоді.

Результати та дискусії. Когнітивна лінгвістика вивчає процеси оперативного мислення людини, з'ясовує роль мови в пізнавальній діяльності людини, а також досліджує зв'язок між концептами різних мов у світі, вивчає людську свідомість, отримання й зберігання знать у мовних одиницях. Основними поняттями когнітивної лінгвістики є концепт та концептосфера.

Як відомо, поняття «концепт» $є$ складним і багатоаспектним феноменом, оскільки сучасна наука поєднує різні аспекти, напрями та підходи до трактування цього поняття. Більшість дослідників погоджуються, що концепт - це одиниця «ментальних і психічних ресурсів нашої свідомості», «оперативна змістовна одиниця пам'яті, ментального лексикону, концептуальної системи й мови мозку (lingua mentalis)» [3]. Концепти виникають у процесі формування інформації про об'єкти та зберігають інформацію про те, що індивід знає, думає, уявляє про об'єкти світу. Мова є основним засобом вираження концепту.

Дослідження концептів та концептосфер передбачає врахування низки факторів. Кожна культура є своєрідною, і важливо розуміти, що концепти відображають національний характер народу, цінності, традиції, звички, спосіб життя людей, менталітет та бачення світу індивідом. Упорядковані у свідомості людини сукупності концептів утворюють концептосфери.

У лінгвістичну термінологію поняття концептосфери вперше ввів Д. С. Лихачов у своїй роботі «Концептосфера російської мови» (1993) [4]. Концептосфери - це сукупність концептів, 
які належать до ментального простору однієї нації, носіїв конкретної мови. Чим багатша культура нації, тим багатша концептосфера мови. Основними чинниками для формування концептосфер є культура, релігія, література, наука в цілому тощо.

Потрібно зазначити, що концептосфери є динамічними за своєю природою, вони мають здатність змінюватися та розвиватись із появою нових понять. У результаті з'являються нові концепти, які надалі стають складовими компонентами концептосфер. Тому поняття «концептосфера» пов'язують із пізнавальним потенціалом, а також обсягом знань та навичок, із культурним досвідом не лише окремого індивіда, а й народу загалом [5]. Одним із способів виявлення структури концептосфер $є$ проведення вільного асоціативного експерименту.

У нашому дослідженні ми провели вільний асоціативний експеримент, який мав на меті виокремити концепти, що утворюють концептосферу української та американської молоді, визначити ядро, приядерну зону й периферію концептосфер двох лінгвокультур.

В експерименті взяло участь 60 респондентів (30 українців та 30 американців) віком від 18 до 25 років. Їм запропоновано написати 10 найбільш актуальних для них слів. Відповідати потрібно було швидко - писати те, що перше спадає на думку. Експеримент був анонімним, тому гендерний аспект не був предметом нашого дослідження. Він був проведеним у письмовій, індивідуальній формі, яка мала певні обмеження в часі.

Українській молоді запропоновано інструкцію: «Ви берете участь в асоиіативному експерименті. Будь ласка, напишіть 10 слів-асоџіаџій, які є найважливішими для вас. Думайте не більше 10-15 секунд». Для американської молоді вона звучала так: «Yои are participating in the associative experiment. Please, write 10 the most important (meaningful) words-associations in your life. Think about 10-15 seconds». Було вирішено не давати в дужках приклади, щоб відповідь респондентів була неупередженою та свідомою.

30 респондентів-українців написали 291 реакцію. Зауважимо, що не всі учасники могли дати по 10 асоціацій. Мінімальна кількість слів була запропонована одним із респондентів, а саме одна асоціація, два респонденти дали по 11 асоціацій, два респондента - 9, 25 10 асоціацій.

Ядерними реакціями є ті, які трапляються не менше ніж 6 разів: сім'я (27), кохання (25), щастя (14), друзі (12), здоров'я (12), розвиток (9), дружба (8), подорож (7), діти (7), успіх (6). До приядерної зони концептосфери належать реакції з частотністю 5-2: добро, розуміння, мама, життя, мрія, віра, свобода, повага, гармонія, щирість, достаток, мудрість - частотність 5; краса, правда - 4, вірність, гроші, підтримка, радість - 3; Я, турбота, правда, сміх, тварина, душа, затишок, впевненість, мир, добробут, натхнення, вдячність- 2. До одиничних периферійних реакцій входять взаємодопомога, момент, сум, комфорт, насолода, навчання, безпека, дім, неповторність, незалежність, Украӥна, спілкування, спорт, відносини, забезпеченість, музика, задоволення, робота, чоловік, прощення, цінність, батьки, честь, Бог, почуття, їжа, вода, пізнання, благополуччя, знання, кар'єра, фігура, коханий, море, тусовка, відпочинок, людина, відвертість, реалізація, ціль, спокій, інтелект, секс, рух, вільність, вибір, енергія, чесність, справжність, людяність, розум, гумор, повітря, люди, самоаналіз, своєчасність, доречність, баланс, поруч, разом. Ці поодинокі реакції є втіленням досвіду конкретних особистостей та утворюють периферію концептосфери.

Отримані слова-реакції є вербалізаторами концептів, котрі утворюють концептосферу української молоді. Ми виокремили такі найбільш актуальні для українців концепти:

1) концепти, що відображають сімейні стосунки, вербалізаторами яких є слова-рекції: сім'я (27), діти (7), мама (5), родина (1), дім (1), відносини (1), чоловік (1), коханий (1), батьки (1);

2) концепти, що відображають ставлення до людей та до себе й об'єктивуються реакціями: кохання (25), друзі (14), дружба (8), повага (5), розуміння (5), гармонія (5), щуирість (5), правда (4), вірність (3), підтримка (3), турбота (2), вдячність (2), упевненість (2), взаємодопомога (1), відвертість (1), відданість (1), справжність (1), людяність (1), самоаналіз (1), поруч (1), разом (1); 
3) концепти, що відображають стан людини; мовними репрезентантами яких є словареакції: здоров'я (12), щяастя (14), свобода (5), радість (3), сміх (2), сум (1), спокій (1), незалежність (1);

4) концепти, що відображають досягнення та об'єктивовані словами: розвиток (9), ycnix (6), достаток (5), гроші (3), кар'єра (1), робота (1), иіль (1).

Отже, ядерними концептами, які утворюють концептосферу української молоді такі концепти, як: СІМ'Я, КОХАННЯ, ЩАСТЯ, ДРУЗІ, ЗДОРОВ'Я, РОЗВИТОК, ДРУЖБА, ПОДОРОЖ, ДІТИ, УСПІХ.

В англомовній частині експерименту було отримано 300 реакцій. Всі учасники дали по 10 асоціацій.

Найчастотнішими є реакції: love (21), family (16), freedom (10) friends (9), trust (9), health (9), life (8), money (8), happiness (7), faith (6), peace (6), loyalty (6). Ці слова-реакції $\mathrm{\epsilon}$ репрезентантами концептів, які утворюють ядро концептосфери американської молоді.

До приядерної зони концептосфери належать асоціації з частотністю 5-2: respect, truth, god, luck, kids, travel, career - частотність 5; honesty, friendship, success, education, wealth, support, future, hope, work-4; goal, genuine, calm, care, adventure, food, dignity, intelligence, excitement, tranquillity - 3; hate, energy, safety, kindness, joy, mother, laughter, sincerity, positivity, stability, independence, rest, inspiration, country - 2 .

Периферійними реакціями є ті, які згадуються лише один раз: circle, patients, accepted, forgiven, ugly, appreciative, positive, dependable, compassion, loving, understanding, parents, music, spouse, serendipitous, authenticity, honor, dream, progress, knowledge, shopping, summer, endlessness, fame, nature, intentional, spirit-filled, bravery, passion, sex, relationship, decision, complete, cherish, imagination, creativity, overcome, strength up, co-creation, curiosity, vulnerability, academia, wife, fraternity, service, harmony, house, university. Усього 48 асоціацій.

Отримані реакції об'єктивують найбільш актуальні концепти, які утворюють концептосферу американської молоді. Було виокремлено такі групи концептів:

1) концепти, що відображають сімейні стосунки й вербалізовані словами-реакціями family (16), friends (9), kids (5) та ін.;

2) концепти, що відображають якості людини. Вони представлені реакціямиприкметниками accepted (1), appreciative (1), positive (1) тощо, і реакціями-іменниками loyalty (6), honesty (4), tranquillity (3) та ін.;

3) концепти, що відображають віру; їхніми вербалізаторами є реакції: God (5), hope (4);

4) концепти, що відображають успіх і достаток та вербалізовані реакціями топеу (8), career (5), success (4) й ін.

Отже, ядерними концептами, які утворюють концептосферу американської молоді, $\epsilon$ LOVE, FAMILY, FREEDOM, FRIENDS, TRUST, HEALTH, LIFE, MONEY, HAPPINESS, FAITH, PEACE, LOYALTY.

Порівняльний аналіз концептосфер української та американської молоді показує, що, незважаючи на низку подібностей у наповненні двох концептосфер, усе ж існують певні відмінності в мовній свідомості українців та американців. Це відображено в наборі концептів, які є найбільш актуальними для представників двох лінгвокультур, та в частотності вживання вербалізаторів цих концептів.

Ядро концептосфери україномовної молоді утворюють 10 концептів, ядро концептосфери американської молоді - 12 концептів.

Найчастотніші ядерні асоціації концептосфери україномовної молоді вербалізують такі концепти, як: СІМ'Я (21\% ядра концептосфери.), КОХАННЯ (20\% ядра концептосфери), ДРУЖБА (16\% ядра концептосфери). ЩАСТЯ (11\% ядра концептосфери), ЗДОРОВ'Я (9 \% ядра концептосфери). Ядро концептосфери американської молоді утворюються концепти: LOVE (який становить $18 \%$ ядра концептосфери), FAMILY (13\% ядра концептосфери), FRIENDS (11\% ядра концептосфери), HEALTH (8\% ядра концептосфери), HAPPINESS (6\% ядра концептосфери). Як бачимо, основні концепти двох концептосфер є універсальними, проте простежемо відмінність щодо вагомості концептів. 
Унікальними в ядрі концептосфери українців є РОЗВИТОК, ПОДОРОЖ, ДІТИ, УСПІХ; у ядрі концептосфери американців такими концептами є FREEDOM, TRUST, LIFE, MONEY, FAITH. Зауважимо, що концепти СВОБОДА, ВІРНІСТЬ, ВIPA, ГРОШІ та ЖИТТЯ теж $є$ актуальними для українців, але вони входять до приядерної зони концептосфери. Для американців значущими є концепти KIDS, TRAVEL SUCCESS, які не потрапили до ядра концептосфери, проте утворюють приядерну зону.

Аналіз приядерної зони концептосфер української й американської молоді показує, що набір концептів, які $є$ актуальними для двох лінгвокультур, дуже схожий. Так, для українців $\epsilon$ важливими такі концепти: ПОВАГА, ЩИРІСТЬ, ДОСТАТОК, ДОБРОБУТ, ПРАВДА, ПІДТРИМКА, ДОБРО, МАМА, СМIX, для американців - RESPECT, SINCERITY, WEALTH, TRUTH, SUPPORT, KINDNESS, MOTHER, LAUGHTER.

Низка концептів, які утворюють приядерну зону концептосфери українців, потрапляють на периферію концептосфери американців i, навпаки, концепти, що належать до приядерної зони концептосфери американської молоді, за даними експерименту, потрапили на периферію концептосфери українців. Зокрема, концепти ГАРМОНІЯ, РОЗУМІННЯ, МРІЯ належать до приядерної зони в україномовній частині експерименту, а концепти HARMONY, UNDERSTANDING, DREAM потрапили на периферію концептосфери американців. Концепти GOD, FOOD, CALM, TRANQUILITY, INTELLIGENCE $є$ складовими частинами приядерної зони концептосфери американців, а концепти БОГ, ЇЖА, СПОКІЙ, ІНТЕЛЕКТ - компонентами периферії концептосфери українців.

Спільними компонентами периферії концептосфер обох лінгвокультур є ДІМ / HOUSE, БАТЬКИ / PARENTS, ЗНАННЯ / KNOWLEDGE, CEKC / SEX тощо.

Отже, за допомогою вільного асоціативного експерименту ми зробили спробу дослідити концептосфери української та американської молоді. Експеримент показав, що складовими частинами концептосфер обох народів $є$ переважно концепти, які мають відповідники в обох лінгвокультурах. Проте спостерігаємо відмінності у вазі важливості концептів.

Висновки. Дослідження концептосфер дає можливість виявити спільні та відмінні риси у культурному досвіді різних народів. За допомогою асоціативного експерименту показано, що концептосфери української та американської молоді утворюють концепти, які не $\epsilon$ унікальними, тобто вони здебільшого мають відповідники в обох лінгвокультурах. Проте вагомість концептів відрізняється: концепти, які формуються ядро концептосфери українців, потрапляють у приядерну зону концептосфери американців, i, навпаки. Спостерігаємо також відмінності у структурі приядерної зони та периферії концептосфер української й американської молоді.

У подальших дослідженнях плануємо дослідити гендерний аспект формування концептосфер.

\section{References}

1. Chernyshenko, Iryna. 2008. "Metody doslidzhennia kontseptiv u kohnitvnii linhvistytsi”. Naukovi zapysky. Seriia: Filolohichni nauky (movoznavstvo) 75 (4): 109-115.

2. Davydenko, Alla. 2018. "Fenomen kontseptu yak odniiei z osnovnykh skladovykh chastyn suchasnoi linhvistyky". Naukovyi visnyk Mizhnarodnoho humanitarnoho universytetu 34 (1): 116-119.

3. Kubryakova, Elena and Valeriy Demiankov, Yuriy Pankrats and Luzina, Lada. 1996. Kratkiy slovar kognitivnykh terminov. Moscow: MGU.

4. Likhachev, Dmitriy. 1993. "Kontseptosfera russkogo yazyka". Izvestiya RAN 52 (1): 3-9.

5. Stepanov, Yuriy. 1997. Konstanty: Slovar russkoy kultury. Moscow: Shkola "Yazyki russkoi kultury".

Бондар Татьяна, Рудая Татьяна. Концептосфера украинской и американской молодежи. В статье рассматриваются ключевые понятия когнитивной лингвистики («концепт» и «концептосферы») и основные методы их исследования, в частности процедуру проведения свободного ассоциативного эксперимента. Ассоциативные эксперименты дают возможность получить спонтанные и беспристрастные реакции, отражающие образ мышления респондентов, их восприятия окружающей действительности, и выделить концепты, образующие концептосферу отдельного индивида, определенной группы людей или народа.

Для описания концептосфер украинской и американской молодежи проводился свободный ассоциативный эксперимент с участием 60 респондентов (30 украинцев и 30 американцев) в возрасте 18-25 лет. Эксперимент был анонимным, поэтому гендерные различия / сходства не рассматривались. В результате получили 591 ассоциацию (респонденты-украинцы - 291, американцы - 300). Слова-реакции являются вербализаторами концептов, актуальных 
для украинской и американской молодежи. Наиболее частотные концепты образуют ядро концептосфер, вербализаторами этих концептов выступают слова-реакции с частотностью шесть и выше. Приядерную зону концептосфер формируют концепты, вербализованные реакциями с частотностью 5-2. Единичные реакции представляют концепты, которые формируют периферию концептосфер.

Ядро концептосферы украиноязычной молодежи образуют 10 концептов (СІМ'Я, КОХАННЯ, ЩАСТЯ, ДРУЗІ, ЗДОРОВ'Я, РОЗВИТОК, ДРУЖБА, ПОДОРОЖ, ДІТИ, УСПІХ), ядро концептосферы американской молодежи - 12 концептов (LOVE, FAMILY, FREEDOM, FRIENDS, TRUST, HEALTH, LIFE, MONEY, HAPPINESS, FAITH, PEACE, LOYALTY). Эксперимент показал, что ключевые концепты двух концептосфер не являются уникальными, то есть они практически не отличаются в двух частях эксперимента. Однако наблюдаем определенные различия в мере важности концептов. Анализ приядерной зоны и периферии концептосфер украинской и американской молодежи подтвердил, что набор концептов, которые актуальны для двух лингвокультур, мало отличается, однако ряд концептов, которые образуют приядерную зону концептосферы украинской молодежи, попадают на периферию концептосферы американцев и, наоборот: концепты, относящейся к приядерной зоне концептосферы американской молодежи, по данным эксперимента, образуют периферию концептосферы украинцев. Таким образом, несмотря на единичные, уникальные ассоциации, полученные от представителей двух лингвокультур, эксперимент показал, что составляющими концептосфер украинской и американской молодежи является преимущественно те, которые имеют эквиваленты в обеих лингвокультурах. эксперимент.

Ключевые слова: концепт, концептосфера, ядро, приядерная зона, периферия, ассоциативный

Bondar Tetiana, Rudaia Tetiana. Conceptospheres of the Ukrainian and American Youth. The article deals with the key concepts of cognitive linguistics («concept» and «conceptosphere») and the main methods of their study, in particular the procedure for conducting a free associative experiment. Associative experiments make it possible to obtain spontaneous and impartial reactions reflecting the way of respondents' thinking and their perception of the surrounding reality. Such experiments help to single out concepts that form the conceptosphere of an individual, a certain group of people or nations.

To describe the conceptospheres of the Ukrainian and American youth, a free associative experiment was conducted which involves 60 respondents (30 Ukrainians and 30 Americans) aged 18-25. The experiment was anonymous, so gender differences / similarities were not considered. As a result of the experiment, 591 associations were obtained (Ukrainian respondents gave 291 reactions, Americans - 300). Those reactions are verbalizers of concepts that are relevant to the Ukrainian and American youth. The most frequent concepts form the nucleus of the conceptospheres, the verbalizers of these concepts being reactions with a frequency of 6 and higher. The near-nuclear zone of the conceptospheres is formed by concepts, verbalized by reactions with a frequency of 5-2. Single reactions represent concepts that form the periphery of conceptospheres.

The nucleus of the conceptosphere of the Ukrainian youth is formed by 10 concepts (СIM'Я, КОХАННЯ, ЩАСТЯ, ДРУЗІ, ЗДОРОВ'Я, РОЗВИТОК, ДРУЖБА, ПОДОРОЖ, ДІТИ, УСПІХ), the nucleus of the conceptosphere of the American youth contains 12 concepts (LOVE, FAMILY, FREEDOM, FRIENDS, TRUST, HEALTH, LIFE, MONEY, HAPPINESS, FAITH, PEACE, LOYALTY). The experiment showed that the key concepts of the two conceptospheres are not unique, that is, they practically do not differ in the two parts of the experiment. However, we observe certain differences in the degree of importance of the concepts. Analysis of the near-nuclear zones and peripheries of the conceptospheres of the Ukrainian and American youth confirmed that the set of concepts that are relevant for the two linguocultures does not differ much. However, some of the concepts that form the nucleus of the Ukrainian youth's conceptosphere appear on the periphery of the Americans' conceptosphere, and vice versa: according to the experiments, concepts related to near-nuclear zone of the conceptosphere of the American youth form the periphery of the conceptosphere of the Ukrainians. Thus, despite the single, unique associations received from representatives of the two linguocultures, the experiment showed that the components of the conceptospheres of the Ukrainian and American youth are mainly concepts that have correspondences in both linguocultures.

Key words: concept, conceptosphere, nucleus, near-nucleus zone, periphery, associative experiment.

DOI: https://doi.org/10.32782/2410-0927-2020-13-6

УДК $811.112 .2 ’ 25-115$

Олена Бондарчук, Наталія Лисецька

\section{КОНЦЕПТУАЛЬНИЙ ПЕРЕКЛАД: ДО ПИТАННЯ ТРАНСФЕРУ КУЛЬТУРНО МАРКОВАНИХ ТЕКСТОВИХ ЕЛЕМЕНТІВ (НІМЕЦЬКА ТА УКРАЇНСЬКА МОВИ)}

У статті проаналізовано культурно марковану лексику як одну з основних труднощів у перекладі. Зосереджено увагу на транслятології як окремій галузі сучасних перекладознавчих досліджень, визначено переклад як об'ємне поняття у тріаді «мова, текст, культура», описано транслятологію як дисципліну з погляду відмінностей лінгвістичного та концептуального перекладу. У науковій розвідці зосереджено увагу на концептуальному перекладі

(C) Бондарчук О., Лисецьька Н., 2020 